$\begin{gathered}\text { Науковий вісник НЛТУ України } \\ \text { Scientific Bulletin of UNFU } \\ \text { https://nv.nltu.edu.ua }\end{gathered}$
$\begin{gathered}\text { https://doi.org/10.15421/40281011 } \\ \text { Article received 15.10.2018 p. }\end{gathered}$
ISSN 2519-2477 (online)
Article accepted 29.11.2018 p.
Удк 502.4.587

Н. П. Шиак ${ }^{1,2}$

${ }^{1}$ Національний природний парк "Кармелюкове Поділля", смт Чечельник, Україна ${ }^{2}$ Уманський національний університет садівництва, м. Умань, Украйна

\title{
ПЛОДОНОШЕННЯ ТА ПРИРОДНЕ ПОНОВЛЕННЯ SORBUS TORMINALIS (L.) CRANTZ ПIД НАМЕТОМ ДУБОВИХ НАСАДЖЕНЬ У ПІВДЕННО-ПОДІЛЬСЬКОМУ ЛІСОСТЕПУ УКРАЇНИ
}

Розглянуто вплив природних чинників на процеси плодоношення та природного поновлення Sorbus torminalis (L.) Crantz (береки лікарської) в дубово-грабових насадженнях. Включення Sorbus torminalis до Червоної Книги України (2009) не $\epsilon$ достатнім для збереження цього виду та його середовища існування. Це лише початковий етап програми зі збереження на території України рідкісних і зникаючих видів. Аналізуючи плодоношення та природне поновлення популяції Sorbus torminalis на території Національного природного парку "Кармелюкове Поділля" та прилеглих територій проходження південносхідної межі поширення виду, з'ясовано залежність плодоношення від сумарної дії комплексу чинників: еколого-біологічних і біометричних. Серед чинників, які впливають на динаміку поновлення береки лікарської у свіжих дібровах, найголовніше значення мають: кліматичні умови, видовий склад деревостану і підросту, повнота, густота, біологія цвітіння (кількість генеративних органів), рясність плодоношення, розміри та маса плодів, особливості проростання насіння, зоогенні чинники. Посушливі 2015-2017 рр. сприяли ранньому дозріванню плодів і швидкому опаданню. Плоди дрібні переважно $з$ однією насіниною. У 2018 р., $з$ вологим і теплим літом, зафіксовано високу врожайність береки лікарської 3 великими, соковитими плодами із двома-трьома дозрілими насінинами. Встановлено, що в дубово-ясеневих насадженнях плоди найдрібніші, рясність плодоношення низька; у дубово-грабових насадженнях - рясність середня, але у дерев, які ростуть на узліссі - рясність висока. Оцінено вагомість абіотичних чинників, які впливають на проростання насіння, розвиток самосіву та підросту головних і супутніх деревних порід. За результатами польових досліджень встановлено, що молоде покоління Sorbus torminalis у дубово-грабових насадженнях поновлюється з насіння, що є своєрідним тестом оцінки життєвості виду. Територія $є$ цінним лісовим масивом південно-східної частини Поділля. У його межах збереглися унікальні природні комплекси, тому поновлення рідкісних рослин відповідає вимогам, що ставляться до створення заказників загальнодержавного значення.

Ключові слова: Sorbus torminalis L.; плодоношення; природне поновлення; дубово-грабові насадження.

Вступ. Одне із завдань лісівництва полягає у формуванні лісів, близьких до природних. Для його вирішення потрібно використати здатність лісових екосистем до природного поновлення. Особливу увагу звертають на збереження і відновлення в лісових масивах рослин, внесених до Червоної книги України. Тому актуальність дослідження зумовлена тим, що випадання береки лікарської (Sorbus torminalis L., Chervona knyha, 2009) у деревостанах спричиняє зниження процесу самовідновлення цього виду в дубових насадженнях та доцільності, 3 огляду на це, вивчення особливостей іiї плодоношення.

Мета дослідження - вивчити та систематизувати чинники, що зумовлюють плодоношення береки лікарської та поновлення iï під наметом дубових насаджень.

Для досягнення поставленої мети передбачено дослідити залежність плодоношення від сумарної дії комплексу чинників. На плодоношення береки лікарської впливають такі чинники:

• еколого-біологічні (температурний режим, родючість і во- логість грунту, освітленість, фенологічні показники, репродуктивний потенціал, періодичність плодоношення);

- біометричні показники вегетативних і генеративних органів (параметри листкової пластинки, приріст пагонів, кількість генеративних органів, розміри та маса плодів);

- положення в системі рослин (види і форми).

Результати дослідження. S. torminalis - це аборигенний вид, занесений до Червоної книги України, компонент другого ярусу світлих широколистяних лісів, мезофіт, кальцефіл. Наукове значення: зникаючий вид. Дерево до 25 м заввишки. Кора сірувато-коричнева, вздовж потріскана. Бруньки голі, округлояйцеподібної форми. Гарне блискуче листя, 16-18 см завдовжки і 510 см завширшки, має широкі лопаті. Квітки невеликі, діаметром 5-7 мм, зібрані у щитоподібні суцвіття. Оцвітина біла. Плід яблуко, 12-15 мм завдовжки та 812 мм діаметром, темно-коричневого або червоно-коричневого забарвлення. Плоди смачні після перших заморозків, тоді вони стають м'якими, приємного смаку, желеподібної консистенції і нагадують смак кураги. Цвіте у квітні-травні, плодоносить у вересні-жовтні. Розмножується насінням. За літературними даними,

\section{Інформація про автора:}

Шпак Ніна Петрівна, наук. співробітник, аспірант. Email: spaknina0@gmail.com

Цитування за ДСтУ: Шпак Н. П. Плодоношення та природне поновлення Sorbus torminalis (L.) Crantz під наметом дубових насаджень у Південно-Подільському Лісостепу України. Науковий вісник НЛтУ України. 2018, т. 28, № 10. С. 53-56.

Citation APA: Shpak, N. P. (2018). Fruiting and natural restoration of Sorbus torminalis (L.) Crantz under the oak stands canopy in the South-Podilsky forest-steppe of Ukraine. Scientific Bulletin of UNFU, 28(10), 53-56. https://doi.org/10.15421/40281011 
охоплює значні площі в Європі, Передній Азії та Північній Африці. В Україні проходить крайня північносхідна межа поширення виду: Закарпаття, Передкарпаття, Північна Бессарабія, Поділля. Окремі локалітети є в Гірському Криму.

Причиною зміни чисельності стало вирубування мішаних широколистяних лісів і заміна їх монокультурами, вибіркове вирубування береки, як цінної деревини, для виготовлення меблів (Bodnar, 2002; Budzhak, 1996; Podillia, 2017a). Дослідження проводили на території південно-східної частини Поділля, яка обмежовувалася

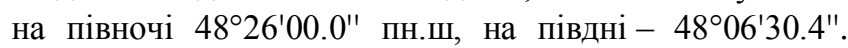
Крайня західна точка - 028 50'25.8", східна $029^{\circ} 24^{\prime} 25.8^{\prime \prime}$.

Південно-Подільський Лісостеп, згідно з фізико-географічним районуванням України, належить до Південної лісостепової зони Подільської височини, яка є частиною Дністровсько-Дніпровської лісостепової провінції Лісостепової зони України. У геоморфологічному відношенні ця ділянка приурочена до західного схилу Українського кристалічного щита (Bodnar \& Hordiienko, 2006; Hordiienko, Bondar \& Krynytskyi, 2006).

Згідно з геоботанічним районуванням України, ця територія належить до Подільсько-Середньопридніпровської провінції Східно-Свропейської провінції Європейсько-Сибірської лісостепової області та знаходиться в Кодимо-Савранському районі скельно дубових та звичайно дубових лісів та південного варіанта лучних степів Ямпільсько-Ананьївського округу дубових лісів із дубів скельного та звичайного, лучних степів і рослинності вапнякових відслонень (Podillia, 2017b; Pohrebniak, 1993).

Природне поновлення та плодоношення береки лікарської досліджували у свіжих дубово-грабових дібровах, які сформовані на потужних темно-сірих опідзолених суглинистих грунтах. С. М. Стойко вважає, що показники природного поновлення є своєрідним тестом оцінки життєвості видів (Stoiko, 2009). Серед чинників, які впливають на динаміку поновлення, найважливіше значення має ярусна структура ценозу, його повнота, густота та видовий склад підросту і підліску, характер трав'яного покриву. Деревостан території дослідження багатоярусний. Перший ярус утворюють дуб звичайний, дуб скельний, ясен звичайний. У другому ярусі переважає граб звичайний з домішками липи серцелистої, кленів гостролистого і польового, береста, береки лікарської, черешні пташиної. Підлісок сформований 3 евтрофних рослин - ліщини, калини гордовини, глоду одноматочкового, бруслини європейської і бородавчатої, дерену справжнього та ін. У підрості переважає граб, ясен, клен. Проективне покриття трав'яних рослин 10-70 \% з перевагою підмаренника справжнього, осоки парвської, копитняка європейського, цибулі ведмежої, медунки темної. Найчастіше трапляється берека лікарська у природних насадженнях ДП "Чечельницьке лісове господарство" і займає 2435,8 га (5,3 \% від площ, вкритих лісовою рослинністю). Найбільша її кількість у стиглих насадженнях - 51,3\%, найменша у молодняках $-11,9$ \% від загальної площі насаджень $з$ їі участю (Podillia, 2017a, 2017b).

За результатами польових досліджень, які проведені протягом 2014-2018 рр., встановлено, що молоде покоління S.torminalis у дубово-грабових насадженнях поновлюється 3 насіння у декілька етапів: плодоношення виду, проростання насіння, утворення сходів, виживання сходів і самосіву, адаптація і розвиток підросту.

Аналіз фенологічних спостережень протягом п'яти років показав, що в дубово-грабових насадженнях цвітіння й утворення зав'язі масове, але рясне цвітіння береки лікарської не гарантує рясного плодоношення. Дозрівання плодів залежить від літніх погодних умов. За 30-40 спекотних літніх днів білышість плодів не дозріває і опадає зеленими вже в липні або в першій декаді серпня. Врожайні роки бувають значно рідше, ніж роки масового цвітіння (таблиця).

Таблиця. Показники біології цвітіння і плодоношення береки лікарської у свіжих дубово-грабових дібровах

\begin{tabular}{|c|c|c|c|c|c|c|}
\hline Рік & $\begin{array}{c}\text { Період } \\
\text { цвітіння }\end{array}$ & $\begin{array}{c}\text { Період зрілості } \\
\text { плодів }\end{array}$ & $\begin{array}{c}\text { Початок опадання } \\
\text { плодів }\end{array}$ & $\begin{array}{c}\text { Середня маса } \\
1000 \text { шт. плодів, г }\end{array}$ & $\begin{array}{c}\text { Середня маса } \\
1000 \text { шт. насінин, г }\end{array}$ & $\begin{array}{c}\text { К-ть плодів в } \\
1 \text { кг }\end{array}$ \\
\hline 2014 & $10-22.05$ & серпень-вересень & кінець серпня & 800 & 21,8 & 1256 \\
\hline 2015 & $14-25.05$ & 3-та декада липня & 2-га декада серпня & 762 & 21,6 & 1318 \\
\hline 2016 & $16-27.05$ & серпень-вересень & 2-га декада вересня & 907 & 1102 \\
\hline 2017 & $07-22.05$ & 2-га декада липня & 1-ша декада серпня & 626 & 17,4 & 1497 \\
\hline 2018 & $12-25.05$ & вересень-жовтень & $\begin{array}{c}\text { 3-та декада вересня- } \\
\text { жовтень }\end{array}$ & 1319 & 24,4 & 758 \\
\hline
\end{tabular}

Посушливі 2015-2017 pp. (з перевагою спекотних днів) сприяли ранньому дозріванню плодів і швидкому опаданню. Плоди дрібні переважно з однією насіниною. Після посушливих попередніх років у 2018 р. 3 вологим і теплим літом зафіксовано високу врожайність береки лікарської з великими, соковитими плодами із двома-трьома дозрілими насінинами (див. таблиця). Кількість плодів великоплідної береки лікарської в одному кілограмі становила в середньому 400 шт.

Порівнявши розміри і вагу зібраних плодів, встановили, що в дубово-ясеневих насадженнях плоди найдрібніші, середня вага плоду - 0,98 г, рясність плодоношення низька (менше 3 кг із 40-річного дерева); в дубово-грабових насадженнях середня вага плоду1,33 г, рясність середня, але у берек, які ростуть на узліссі - рясність висока (6-8 кг із 30-40-річних дерев). У кварталі 90 виділ 4 на відкритому місці виявили дві ве- ликоплідні береки зі середньою вагою плодів 2,58 г і високою рясністю. 3 одного 30-річного дерева зібрали 12,5 кг плодів (2018 р.).

У природних насадженнях не все якісне насіння дає сходи. Проростання насіння залежить від того, як плоди зберігаються після опадання. Якщо плоди підсихають, то насіння не проростає. Причиною є те, що міцна шкірка плоду не дає пробитися зародковому корінцю через неї. Після збору плодів, через 3-5 днів, потрібно відібрати насіння методом вимивання і просушити. Якщо висів проводити восени, то повністю висушувати насіння не рекомендуємо. Для закладання насіння на стратифікацію сухе насіння зберігають у скляному посуді, перед висівом потрібно замочити на 3-5 годин.

Плоди береки лікарської є кормом для птахів і наземних гризунів - це є однією з причин недостачі насін- 
ня в лісі. На виживання сходів береки лікарської має вплив підріст граба, ясена, щільний трав'яний покрив, які пригнічують не тільки сходи, але й підріст (Gorshenin \& Shvidenko, 1977; Pohrebniak, 1993).

Для вивчення лісопоновлювальних процесів насамперед встановлювали кількість підросту, ступінь його життєздатності під наметом деревостану різної зімкнутості в найпоширеніших умовах лісу. Для цього було закладено 11 постійних пробних площ і 31 тимчасову пробну площу. Облік поновлення під наметом лісу та на зрубах проводили, використовуючи методики С. С. П'ятницького (Piatnitckii, 1994), М.М.Горшеніна (Gorshenin \& Shvidenko, 1977), згідно з якими на пробній площі рівномірно закладали облікові площадки $10 \mathrm{M}^{2}$ (за середньої густоти підросту) і $20 \mathrm{~m}^{2}$ (за рідкого підросту), на яких щорічно визначали видовий склад підросту, його кількість і вік. На підставі отриманих даних оцінювали успішність поновлення. На кожній пробній площі описували видову насиченість трав і загальне проективне покриття кожного виду з переведенням його кількості на один гектар, замірами висоти і визначенням віку, густоти, життєздатності та характером розміщення на площі. Біологічною особливістю береки під час природного поновлення є здатність зберігати тривалий час життєвість за недостачі освітлення, але після п'ятирічного віку самосів випадає, якщо в підрості переважає граб або ясен, а в культурах високий трав'яний покрив. За шкалою оцінки природного відновлення М. М. Горшеніна берека має незадовільну категорію відновлення. Вегетативне поновлення береки в природних насадженнях не виявлено. Під час освітлення і прорідження культур дуба звичайного з участю береки лікарської наявне вегетативне поновлення від пеньків по 4-5 рівноцінних паростків береки. Після скушування пагонів береки зайцями, козами - вона також відновлюється.
Висновки. Отже, територія є цінним лісовим масивом південно-східної частини Поділля. В його межах збереглися унікальні природні комплекси, тому поновлення рідкісних рослин відповідає вимогам, що ставляться до створення заказників загальнодержавного значення. Існуюча на цій території сітка природно-заповідних ділянок (ботанічні заказники місцевого значення "Червоногребельський", "Вербська дача", ботанічний заказник загальнодержавного значення "Бритавський") певною мірою забезпечують збереження та відновлення рідкісних видів, але вона потребує подальшого вдосконалення і розширення. Потрібно ширше вводити береку лікарську в лісові культури дуба звичайного.

\section{Перелік використаних джерел}

Bodnar, A. O. (2002). Bereka v lisovykh nasadzhenniakh, (pp. 4-22). Vinnytsia, 234 p. [In Ukrainian].

Bodnar, A. O., \& Hordiienko, M. I. (2006). Formuvannia lisovykh nasadzhen u dibrovakh Podillia, (pp. 237-284). Kyiv, 320 p. [In Ukrainian].

Budzhak, V. V. (1996). Bereka (Sorbus torminalis (L.) Crantz) u pivnichnii Bukovyni ta pivnichnii Bessarabii (khronolohiia, bioekolohiia, okhorona). Doctoral Dissertation for Biology Sciences (03.00.12 - Plant Physiology). Chernivtsi, 293 p. [In Ukrainian].

Gorshenin, N. M., \& Shvidenko, A. I. (1977). Lesovodstvo. Lviv, 304 p. [In Russian].

Hordiienko, M. I., Bondar, A. O., \& Krynytskyi, H. T. (2006). Lisovi nasadzhennia Vinnychchyny. Kyiv, 248 p. [In Ukrainian].

Piatnitckii, S. S. (1994). Lesovozobnovlenie v usloviiakh levoberezhnoi Lesostepi. (Vol. 45). Lesorazvedenie i vozobnovleniem, (pp. 3-23). Kyiv, 340 p. [In Russian].

Podillia. (2017a). Litopys pryrody NPP "Karmeliukove Podillia". (Vol. 4). Chechelnyk, 141 p. [In Ukrainian].

Podillia. (2017b). Litopys pryrody NPP "Karmeliukove Podillia". (Vol. 5). Chechelnyk, 86 p. [In Ukrainian].

Pohrebniak, P. S. (1993). Lisova ekolohiia i typolohiia lisiv, (pp. 136141). Kyiv, 320 p. [In Ukrainian].

Stoiko, S. M. (2009). Dubovi lisy Ukrainskykh Karpat: ekolohichni osoblyvosti, vidtvorennia, okhorona, (pp. 151-155). Lviv, 260 p. [In Ukrainian].

Н. П. Шnак ${ }^{1,2}$

${ }^{1}$ Нацииональный природный парк "Кармелюково Подолье", пгт Чечельник, Украина ${ }^{2}$ Уманский национальный университет садоводства, г. Умань, Украина

\section{ПЛОДОНОШЕНИЕ И ЕСТЕСТВЕННОЕ ВОССТАНОВЛЕНИЕ SORВUS TORMINALIS (L.) CRANTZ В ДУБОВЫХ НАСАЖДЕНИЯХ ЮГО-ПОДОЛЬСКОЙ ЛЕСОСТЕПИ УКРАИНЫ}

Рассмотрено влияние естественных факторов на процессы плодоношения и возобновления Sorbus torminalis (L.) Crantz (береки лекарственной) в дубово-грабовых насаждениях. Введение Sorbus torminalis в Красную книгу Украины (2009) не гарантирует достаточную степень сохранения этого вида и его среды обитания. Это только начальный этап программы по сохранению на территории Украины редких и исчезающих видов. Анализируя плодоношения и естественное возобновление популяции Sorbus torminalis на территории национального природного парка "Кармелюкове Подолье" и прилегающих территорий прохождения юго-восточной границы распространения вида, выяснено зависимость плодоношения от суммарного воздействия комплекса факторов: эколого-биологических и биометрических. Среди факторов, влияющих на динамику обновления Sorbus torminalis в свежих дубравах, главное значение имеют: климатические условия, видовой состав древостоя и подроста, полнота, плотность, биология цветения (количество генеративных органов), обильность плодоношения, размеры и масса плодов, особенности прорастания семян, зоогенные факторы. Засушливые 2015-2017 годы способствовали раннему созреванию плодов Sorbus torminalis и быстрому осыпанию, плоды мелкие. В 2018 году, с влажным и теплым летом, зафиксирована высокая урожайность с большими, сочными плодами с двумя-тремя созревшими семенами. В результате исследований установлены различия плодоношення вида: в дубово-ясеновых насаждениях - плоды мелкие, обильность плодоношения низкая; в дубово-грабовых - плоды и обильность средние, у деревьев, растущих на опушке, обильность высокая. Дана оценка весомости абиотических факторов, которые влияют на прорастания семян, развитие самосева и подроста главных и сопутствующих древесных пород. По результатам полевых исследований, установлено, что молодое поколение Sorbus torminalis в дубово-грабовых насаждениях возобновляется из семян. Территория является ценным лесным массивом юго-восточной части Подолья. В его пределах сохранились уникальные лесные масивы, поэтому возобновление редких растений соответствует требованиям, предъявляемым к созданию заказников общегосударственного значения.

Ключевые слова: Sorbus torminalis L.; 


\section{FRUITING AND NATURAL RESTORATION OF SORBUS TORMINALIS (L.) CRANTZ UNDER THE OAK STANDS CANOPY IN THE SOUTH-PODILSKY FOREST-STEPPE OF UKRAINE}

The article discusses the influence of natural factors on fruiting and natural regeneration of Sorbus torminalis (L.) Crantz in oakhornbeam stands. The inclusion of Sorbus torminalis in the Red Book of Ukraine (2009) is not sufficient to save this species and its habitat. This is only the initial stage of the program for the conservation of rare and endangered species in Ukraine. Analyzing the fruiting and natural resumption of Sorbus torminalis stands in the territory of Karmelyukove Podillya National Nature Park and the adjacent territories of the south-eastern distribution of the species, the dependence of fruiting on the total impact of complex factors such as environmental, biological, and biometric. Among the factors affecting the dynamics of renewal of the medicinal stalk in fresh oak forests, the following are of primary importance: climatic conditions, species composition of the stand and undergrowth, fullness, density, flowering biology (number of generative organs), abundance of fruiting, size and weight of fruits, seed germination features, and zoo factors. Droughty period of 2015-2017 facilitated the early ripening of Sorbus torminalis fruits and rapid deprivation. A moist and warm summer in 2018 caused quite a high productivity of large juicy fruits with two or three ripen seeds. The abundance of trees in the oak-ashen stands is found to be average, trees growing on the edge of the wood present high abundance. The authors have assessed the importance of abiotic factors influencing seed germination, the development self-sowing and undergrowth of main and accompanying tree species. According to the results of field research, we have revealed that the young generation of Sorbus torminalis in oak-hornbeam stands is renewed from seeds. Indicators obtained from natural renewal Sorbus torminalis, which is a kind of test assessing of species vitality. The territory is a valuable forest massif in the south-eastern part of Podillya. Within its borders, unique natural complexes have been preserved, therefore the renewal of rare plants meet the requirements for creating reserves of national importance.

Keywords: Sorbus torminalis L.; fruiting; natural renewal; oak-hornbeam plantations. 